\title{
Phytoplankton pigments in the deep chlorophyll maximum of the Caribbean Sea and the western tropical Atlantic Ocean
}

\author{
George B. McManus ${ }^{1,2}$, Rodger Dawson ${ }^{3}$ \\ ${ }^{1}$ Marine Environmental Sciences Consortium, Dauphin Island Sea Lab, Box 369, Dauphín Island, Alabama 36528, USA \\ ${ }^{2}$ Department of Marine Sciences, University of South Alabama, Mobile, Alabama 36688, USA \\ ${ }^{3}$ Chesapeake Biological Laboratory, Center for Environmental and Estuarine Studies, University of Maryland System, Box 38, \\ Solomons, Maryland 20688, USA
}

\begin{abstract}
We report on the distribution of chlorophylls and carotenoids in the deep chlorophyll maximum (DCM) of the western tropical Atlantic and the Caribbean Sea, focusing on pigments of picophytoplankton. Prochlorococcus-like cells consistently were the dominant component of the DCM phytoplankton community, with divinyl chlorophyll a being a nearly-constant $38 \%$ of total chlorophyll a. Coccoid cyanobacteria were 1 to 2 orders of magnitude less abundant at all stations and depths. Prochlorococcus-like cells in the deeper parts of the DCM contained large amounts of chlorophyll $b$, often more than twice as much as divinyl chlorophyll $a$, suggesting the possibility of chromatic adaptation to increasing proportions of blue-green light at the bottom of the euphotic zone. Based on flow cytometry estimates of cell abundance, divinyl chlorophyll a per cell also increased dramatically through the DCM, with values ranging from 0.09 to $1.45 \mathrm{fg}$ cell $^{-1}$ The carotenoids 19'-hexanoyl-oxy-fucoxanthin and 19'-butanoyl-oxy-fucoxanthin increased with depth in the DCM in relation to both total chlorophyll $a$ and non-divinyl chlorophyll a, supporting the idea that eukaryotic nano- and picoplankters comprise a higher portion of the phytoplankton community in the deeper portions of the DCM in the tropics.
\end{abstract}

KEY WORDS: Prochlorophyte - Cyanobacteria - Picoplankton Chlorophyll - Divinyl - Carotenoid - Flow cytometry

Deep chlorophyll maxima (DCM) are found throughout the world's oceans, but are deepest and most persistent in the tropics, where they occur at or near the base of the euphotic zone (reviewed by Cullen 1982). Picophytoplankton comprise a significant portion of the photosynthetic biomass in the DCM of the tropics (Takahashi \& Hori 1984). These small phototrophs are abundant in most oceanic waters (Li et al. 1983, Takahashi \& Hori 1984, Stockner \& Antia 1986), and can account for more than half of the primary production in oligotrophic regions (e.g. Iturriaga \& Mitchell
1986, Jochem \& Zeitzschel 1993). The group includes the coccoid cyanobacteria, some prasinophytes and other small eukaryotic algae (Johnson \& Sieburth 1982, Gieskes \& Kraay 1986, Glover et al. 1986a), as well as the recently-described prochlorophyte-like bacteria (Chisholm et al. 1988, 1992). The latter contain unique, 'divinyl' forms of both chlorophyll $a$ and $b$ (Goericke \& Repeta 1992). Because they contain chl b, these picoplankters have been referred to as prochlorophytes', though they are probably closely related to the coccoid cyanobacteria (Palenik \& Haselkorn 1992, Urbach et al. 1992). They are widely distributed in tropical and subtropical, open ocean waters, though they also have been reported from temperate latitudes and in nearshore waters of the Great Barrier Reef and the Mediterranean (Li \& Wood 1988, Olson et al. 1990 , Vaulot et al. 1990, Campbell \& Vaulot 1993, Goericke \& Repeta 1993, Goericke \& Welschmeyer 1993, Shimada et al. 1993). Some data suggest that in the tropics prochlorophytes are mainly associated with the DCM (Shimada et al. 1993), while others have shown more uniform vertical distributions of prochlorophytes in waters possessing a DCM (Campbell \& Vaulot 1993).

A large number of studies have demonstrated the differences in species composition among phytoplankton in surface and DCM communities (cf. Venrick 1993 and references therein), but less attention has been paid to zonation within the DCM itself. Some evidence suggests that pico-eukaryotes are relatively more abundant below the DCM peak, and that they are better adapted to the spectral quality of light there (Furuya \& Marumo 1983, Murphy \& Haugen 1985. Glover et al. 1986a, b, 1987).

We report here on the distribution of carotenoids, and of chlorophyll $a$, total chlorophyll $b$ (normal and 
divinyl forms), and divinyl chlorophyll a (hereafter referred to as chl $a_{1}$, chl $b$, and chl $a_{2}$, respectively) in neritic waters of the Caribbean Sea and the western tropical Atlantic Ocean. Our focus was on the DCM zone, ca 80 to $120 \mathrm{~m}$ below the surface, and on changes in the relative abundance of different chlorophylls and carotenoids with depth within it. Our aim was to use changes in pigment concentrations to evaluate the relative importance of prochlorophytes, zonation of different picophytoplankton populations within the DCM, and possible adaptation of cell pigment content to changing quantity and quality of light at the base of the euphotic zone.

Materials and methods. We participated in 2 cruises, in January/February 1991 and January 1992. The study area ranged from the Atlantic Ocean side of the southern Bahamas to Guadeloupe. Most samples were taken in nearshore waters on the Caribbean side off Guadeloupe, Montserrat, and the U.S. Virgin Islands (Fig. 1, Table 1).

At each station, a rosette fitted with 10 or $30 \mathrm{l}$ Niskin sampling bottles, a CTD, and an in situ fluorometer (Sea Tech, Inc.) was deployed to a depth of approximately $200 \mathrm{~m}$. The down trace of fluorescence was used to locate the DCM and samples were collected on the way up. Most often, we sampled at the bottom of the DCM, twice within it, and at its top. On some occasions, samples were also taken near the surface $(5 \mathrm{~m})$, or well below the DCM (e.g. $200 \mathrm{~m}$ ). Some stations were sampled for nutrient concentrations; measured using standard methods (Parsons et al. 1984). Light attenuation was estimated at several stations with a $30 \mathrm{~cm}$ diameter white Secchi disk. In addition, 2 profiles of spectrally resolved downwelling irradiance were made, using a Biospherical Instruments MER 1000 spectral radiometer with a $2 \pi$ light sensor, 12 spectral bands plus PAR, and a pressure sensor for depth. The maximum depth for this instrument was $85 \mathrm{~m}$.

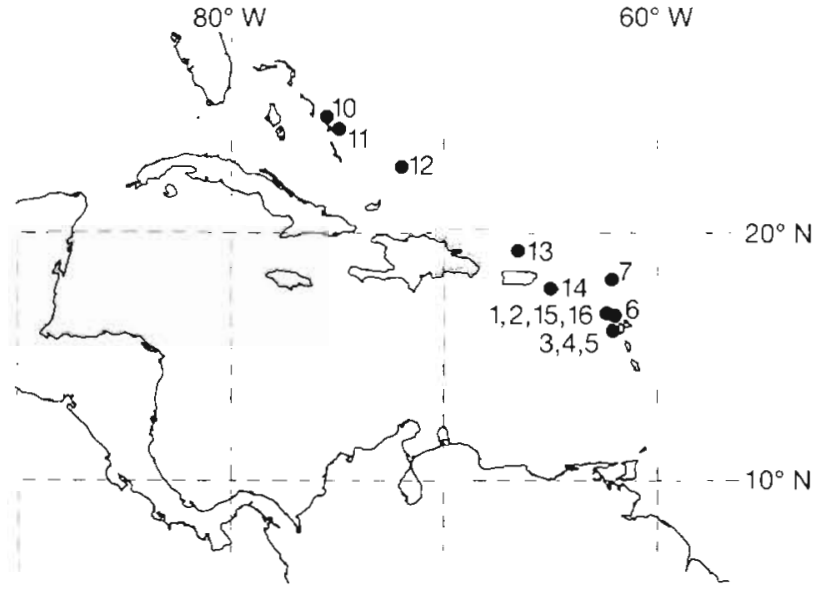

Fig. 1. Station locations, Atlantic Ocean side of the southern Bahamas to Guadeloupe

We experimented with filtration methods for collecting pigments after abandoning early attempts to use glass fiber filters $(\mathrm{GF} / \mathrm{F})$ because our extraction efficiencies were low, even after sonication and freezing to rupture cells. On the 1991 cruise we used $47 \mathrm{~mm}$, $0.4 \mu \mathrm{m}$ pore size, polyester Nuclepore filters (Hooks et al. 1988), and filtered 2.3 to $10 \mathrm{l}$ of sample. However, flow cytometry samples analyzed after that cruise showed that some picoplankton were passing through these filters. We therefore used $47 \mathrm{~mm}, 0.2 \mu \mathrm{m}$ pore size ceramic Anodisc filters (Anotec, Inc.) on the 1992 cruise. All samples from the 1992 cruise were of 2.3 l volume.

Following filtration of water samples, filters were placed in microcentrifuge tubes with 0.5 or $1.0 \mathrm{ml}$ of acetone. When the Anodisc filters were used, the plastic support ring was removed before extraction. To do this, we placed each filter in a Whirlpak plastic bag and crushed it into small pieces. The ring was then removed and the pieces 'poured' onto a glass plate

Table 1. Station list

\begin{tabular}{|ccccc|}
\hline Date & Stn & Time of day & Location & \\
\hline 31 Jan 1991 & 1 & $11: 00 \mathrm{~h}$ & $16^{\circ} 42^{\prime} \mathrm{N}, 62^{\circ} 26^{\prime} \mathrm{W}$ & Sample \\
1 Feb 1991 & 2 & $10: 15 \mathrm{~h}$ & $16^{\circ} 46^{\prime} \mathrm{N}, 62^{\circ} 21^{\prime} \mathrm{W}$ & Chlorophylls \\
5 Feb 1991 & 3 & $12: 30 \mathrm{~h}$ & $15^{\circ} 58^{\prime} \mathrm{N}, 61^{\circ} 59^{\prime} \mathrm{W}$ & Chlorophylls, carotenoids \\
7 Feb 1991 & 4 & $09: 30 \mathrm{~h}$ & $16^{\circ} 09^{\prime} \mathrm{N}, 62^{\circ} 05^{\prime} \mathrm{W}$ & Chlorophyll, carotenoids \\
8 Feb 1991 a.m. & 5 & $05: 30 \mathrm{~h}$ & $16^{\circ} 07^{\prime} \mathrm{N}, 62^{\circ} 04^{\prime} \mathrm{W}$ & Chlorophylls, carotenoids \\
8 Feb 1991 p.m. & 6 & $16: 00 \mathrm{~h}$ & $16^{\circ} 34^{\prime} \mathrm{N}, 61^{\circ} 59^{\prime} \mathrm{W}$ & Chlorophylls, carotenoids, flow cytometry \\
9 Feb 1991 & 7 & $19: 15 \mathrm{~h}$ & $18^{\circ} 06^{\prime} \mathrm{N}, 62^{\circ} 09^{\prime} \mathrm{W}$ & Chlorophylls, carotenoids, flow cytometry \\
18 Jan 1992 a.m. & 10 & $11: 00 \mathrm{~h}$ & $24^{\circ} 39^{\prime} \mathrm{N}, 75^{\circ} 29^{\prime} \mathrm{W}$ & Chlorophylls \\
18 Jan 1992 p.m. & 11 & $18: 00 \mathrm{~h}$ & $24^{\circ} 11^{\prime} \mathrm{N}, 74^{\circ} 59^{\prime} \mathrm{W}$ & Chlorophylls \\
21 Jan 1992 & 12 & $13: 00 \mathrm{~h}$ & $22^{\circ} 38^{\prime} \mathrm{N}, 71^{\circ} 59^{\prime} \mathrm{W}$ & Chlorophylls \\
22 Jan 1992 & 13 & $10: 40 \mathrm{~h}$ & $19^{\circ} 15^{\prime} \mathrm{N}, 66^{\circ} 32^{\prime} \mathrm{W}$ & Chlorophylls \\
23 Jan 1992 & 14 & $13: 35 \mathrm{~h}$ & $17^{\circ} 44^{\prime} \mathrm{N}, 64^{\circ} 55^{\prime} \mathrm{W}$ & Chlorophylls \\
27 Jan 1992 & 15 & $18: 00 \mathrm{~h}$ & $16^{\circ} 44^{\prime} \mathrm{N}, 62^{\circ} 17^{\prime} \mathrm{W}$ & Chlorophylls \\
29 Jan 1992 & 16 & $18: 05 \mathrm{~h}$ & $16^{\circ} 44^{\prime} \mathrm{N}, 62^{\circ} 17^{\prime} \mathrm{W}$ & Chlorophylls \\
& & & \\
\hline
\end{tabular}


and scraped into the microcentrifuge tube with a razor blade. No pigment was left behind in the bags, as indicated by acetone rinses and separate comparisons with parallel filters crushed outside the bags on a glass plate. This procedure allowed us to extract the pigments in as little as $0.5 \mathrm{ml}$ of acetone. Once in the tubes with acetone, samples were frozen in liquid nitrogen, thawed, and sonicated for 3 to $5 \mathrm{~min}$ in an ice bath. They were then left to extract for several hours at $-20^{\circ} \mathrm{C}$. For the 1991 cruise, all samples were analyzed on board ship. For the 1992 cruise, samples were stored in an ultra-low freezer $\left(-80^{\circ} \mathrm{C}\right)$ and analyzed within $4 \mathrm{mo}$.

Chlorophylls were separated and quantified by highperformance liquid chromatography (HPLC Fig. 2A).

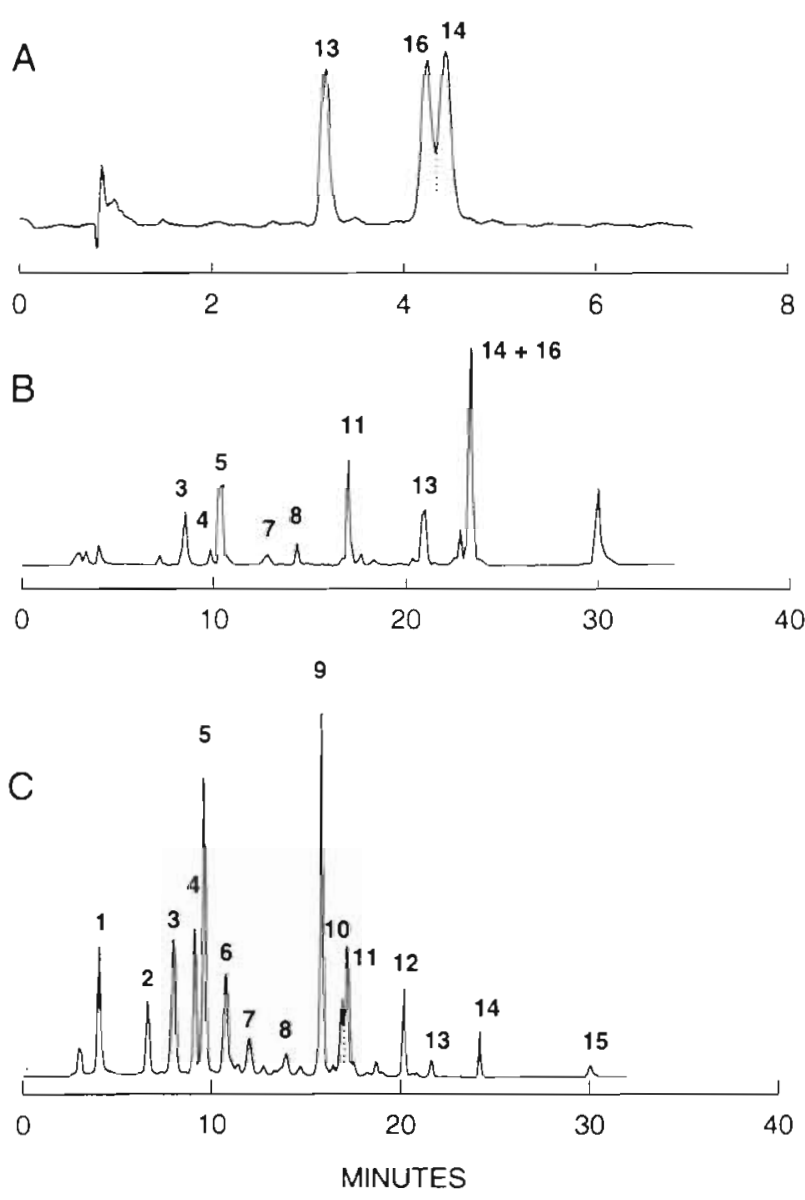

Fig. 2. Absorbance chromatograms for the sample from $\operatorname{Stn} 7_{\text {, }}$ $120 \mathrm{~m}$. (A) $658 \mathrm{~nm}, \mathrm{C}-8$ column, showing chl $a_{1}$ and chl $a_{2}$ separation; (B) $436 \mathrm{~nm}, \mathrm{C}-18$ column, showing carotenoid separations. (C) Mixed standard used to verify retention times (436 nm absorbance). $1=$ chlorophylls $c 1+c 2 ; 2=$ peridinin $_{i}$ $3=19^{\prime}$-butanoyl-oxy-fucoxanthin; $4=$ fucoxanthin; $5=19^{\prime}$ hexanoyl-oxy-fucoxanthin; $6=$ cis-19' -hexanoyl-oxy-fucoxanthin; $7=$ prasinoxanthin; $8=$ diadinoxanthin; $9=$ alloxanthin; $10=$ lutein; $11=$ zeaxanthin $12=$ canthaxanthin; $13=\mathrm{chl} b$; $14=\operatorname{chl} a_{1} ; 15=\beta$-carotene $; 16=\operatorname{chl} a_{2}$
Solvent A was 90:10 (methanol:0.25 M aqueous ammonium acetate); solvent $B$ was acetonitrile. Best separations were achieved using a linear gradient from $50 \%$ to $100 \% \mathrm{~B}$ in $14 \mathrm{~min}$ at $1 \mathrm{ml} \mathrm{min} \mathrm{m}^{-1}$, with a $3 \mathrm{~min}$ reequilibration to initial conditions between injections. The column was a $0.46 \times 15 \mathrm{~cm}, 5 \mu \mathrm{m} \mathrm{C-8}$ (Rainin, Inc.) Injection volume was 100 to $200 \mu \mathrm{l}$, and all samples were treated with ion-pairing reagent (Mantoura \& Llewellyn 1983).

We used pure chl $a_{1}$ and chl $b$ (Sigma Chemical Co.) to convert peak areas to pigment concentrations. Detection was by absorbance at $658 \mathrm{~nm}$, where chl $a_{1}$ and chl $a_{2}$ both have maxima (cf. Gieskes \& Kraay 1983, Rowan 1989, Goericke \& Repeta 1992). We assumed molar extinction coefficients were identical for both forms of chl a.

On the 1991 cruise, HPLC estimates of carotenoid concentrations were also made at 6 of the 7 stations (Fig. 2B, Table 1). These were done by absorbance at $436 \mathrm{~nm}$, after separation on a $0.46 \times 25 \mathrm{~cm}$ Adsorbosphere (Alltech) C-18 column, using a solvent system similar to that of Wright \& Shearer (1984; 85:15 methanol in ammonium acetate buffer, switched to 90:10 acetonitrile:water after $4 \mathrm{~min}$, then to a linear gradient to $100 \%$ ethyl acetate in $25 \mathrm{~min}$ ). This gradient allowed us to quantify lutein and zeaxanthin separately (Fig. 2C). The system was initially calibrated with pure standards of various carotenoids, isolated from phytoplankton cultures and quantified spectrophotometrically (Wright et al. 1991, Bianchi et al. 1993). Response factors relative to chl $a_{1}$ were calculated for our particular gradient system and detector, and routine calibrations were performed with pure chl $a_{1}$. The fucoxanthin response factor was used for 19'-hexanoyl-oxy-fucoxanthin and 19'-butanoyl-oxyfucoxanthin. A mixed standard of 15 known carotenoids was used to verify retention times regularly (Fig. 2C). Separation of chl $a_{1}$ and chl $a_{2}$ was not reliable with this solvent system.

At 3 stations on the 1991 cruise, water samples were collected to estimate picoplankton cell abundances by flow cytometry. One ml samples were preserved with $0.1 \%$ (final concentration) glutaraldehyde, held at $4^{\circ} \mathrm{C}$ for $10 \mathrm{~min}$, then transferred to liquid nitrogen until they could be counted 6 mo later) with a Coulter EPICS V flow cytometer (Olson et al. 1990, 1993). Excitation was at $488 \mathrm{~nm}(500 \mathrm{~mW}$, focused by a $38 \mathrm{~mm}$ spherical lens), and a Profile flow cell was used with a restrictor to reduce flow rate to approximately $2 \mathrm{~m} \mathrm{~s}^{-1}$. Integrated forward light scatter $\left(1.5\right.$ to $\left.19^{\circ}\right)$, right angle scatter $\left(73\right.$ to $\left.107^{\circ}\right)$, red fluorescence $(660$ to $700 \mathrm{~nm})$, and orange fluorescence $(515$ to $630 \mathrm{~nm})$ signals were collected for each cell and for uniform fluorescent microspheres (0.57 $\mu \mathrm{m}$ diameter 'Fluoresbrite', Polysciences, Inc., 
Warrington, PA, USA) added as internal standards The data were analyzed using software provided by D. Vaulot (CYTOPC).

Results. Water transparency was typical of that for oligotrophic waters, with Secchi depths ranging from ca 30 to $50 \mathrm{~m}$. The attenuation coefficient for photosynthetically active radiation (PAR) was $0.048 \mathrm{~m}^{-1}$; thus the $1 \%$ light depth was at about $95 \mathrm{~m}$. As with other case I waters, attenuation was least for blue-green light, with minimum attenuation somewhere between 441 and 507 nm (Table 2).

A typical vertical profile of temperature, salinity, and fluorescence is shown in Fig. 3A, along with measurements of prochlorophyte abundance and nitrate + nitrite concentrations at discrete depths through the DCM. The DCM itself was usually sharp, and had its peak within the pycnocline or just at the base of the mixed layer, and appeared to be associated with the top of the nitracline. Prochlorophytes were by far the most abundant picoplankton in the DCM, ranging up to 187000 cells $\mathrm{ml}^{-1}$, and comprising $>90 \%$ of total phytoplankton cells at all DCM depths (Table 3). Syne-

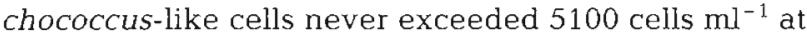
our 3 flow cytometry stations.

Data on chlorophylls $a_{1}, a_{2}$, and $b$ are superimposed on the fluorescence profile from the same station (Stn 5) in Fig. 3B. All 3 chlorophylls exhibited sharp peaks in the DCM at all stations, with the chl $b$ peak usually being deepest. Over all stations and depths
Table 2. Light extinction at Stn 16. Attenuation coefficients (k) were calculated from log-transformed linear regressions of downwelling irradiance vs depth. PAR: photosynthetically active radiation

\begin{tabular}{|ccc|}
\hline Wavelength $(\mathrm{nm})$ & $k\left(\mathrm{~m}^{-1}\right)$ & $\mathrm{SE}(\mathrm{n})$ \\
\hline 410 & 0.040 & $0.0003(151)$ \\
441 & 0.037 & $0.0003(151)$ \\
488 & 0.035 & $0.0002(151)$ \\
507 & 0.042 & $0.0002(151)$ \\
520 & 0.057 & $0.0006(151)$ \\
540 & 0.075 & $0.0007(151)$ \\
570 & 0.103 & $0.0023(51)$ \\
589 & 0.135 & $0.0028(41)$ \\
625 & 0.384 & $0.0055(18)$ \\
656 & 0.477 & $0.0137(17)$ \\
675 & 0.543 & $0.0133(16)$ \\
694 & 0.637 & $0.0100(14)$ \\
PAR & 0.048 & $0.0005(151)$ \\
& & \\
\hline
\end{tabular}

(except samples of $200 \mathrm{~m}$ or deeper), the fraction of total chl a represented by chl $a_{1}$ was remarkably constant, at $0.384 \pm 0.02$ (mean and $95 \%$ confidence interval; $n=62$ ). This includes the 5 surface samples, which averaged 0.358 .

The principal carotenoids were 19'-butanoyl-oxyfucoxanthin, 19'-hexanoyl-oxy-fucoxanthin, and zeaxanthin, with smaller amounts of fucoxanthin, peridinin, diadinoxanthin, and prasinoxanthin, and virtually no lutein (Fig. 2B)

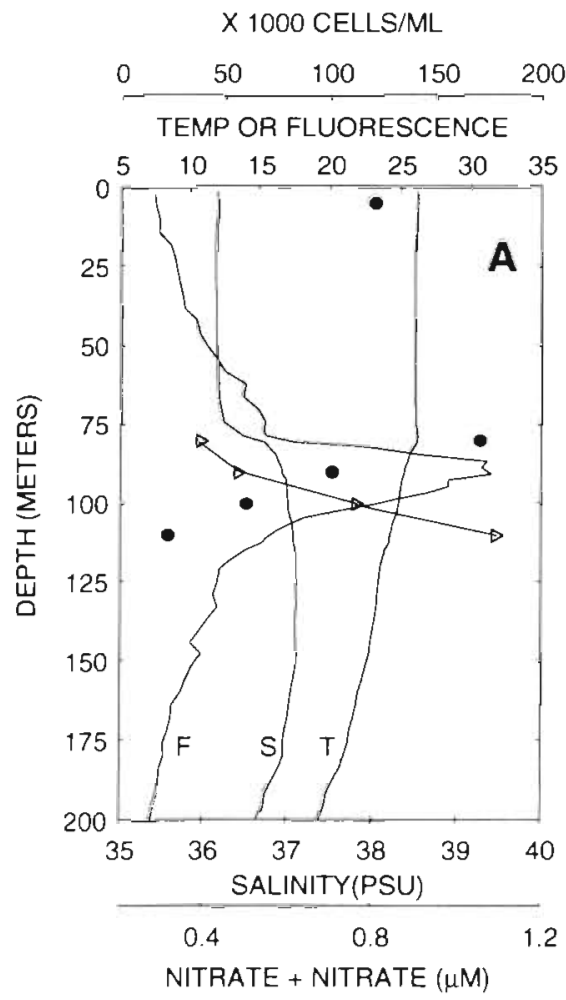

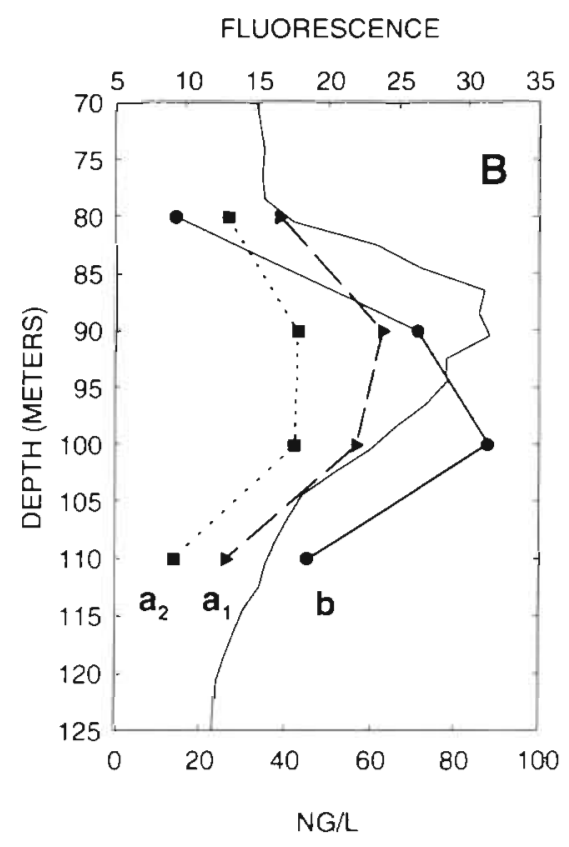

Fig. 3. Stn 5. (A) Vertical pro files of fluorescence ( $F$, arbitrary units), salinity (S), and temperature $\left(T,{ }^{\circ} \mathrm{C}\right)$, with superimposed nutrient concentrations $(\triangleright)$ and flow cytometer counts of prochlorophytes $(\bullet)$ (B) The same fluorescence profile, expanded to emphasize the DCM, with chla, $(\bullet)$, chla

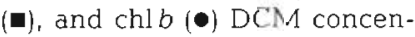
trations superimposed 
Table 3. Cell counts and chlorophyll data for stations where flow cytometer samples were taken during the $1991 \mathrm{cruise}$. nd: not detectable; chl $a_{1}$ : chlorophyll $a_{i}$ chl $a_{2}$ : divinyl chlorophyll $a$

\begin{tabular}{|c|c|c|c|c|c|c|c|}
\hline $\operatorname{Stn}$ & $\begin{array}{l}\text { Depth } \\
\text { (m) }\end{array}$ & $\begin{array}{l}\text { Prochlorophytes } \\
\text { (cells ml } \mathrm{ml}^{-1} \text { ) }\end{array}$ & $\begin{array}{l}\text { Coccoid cyanobacteria } \\
\text { (cells ml } \mathrm{m}^{-1} \text { ) }\end{array}$ & $\begin{array}{l}\text { Eukaryotes } \\
\text { (cells } \mathrm{ml}^{-1} \text { ) }\end{array}$ & $\begin{array}{l}\mathrm{Chl} a_{2} \\
\left(\mathrm{ng} \mathrm{1^{-1 }}\right)\end{array}$ & $\begin{array}{c}\text { Chla } \\
(\text { fg cell } \\
\end{array}$ & $\begin{array}{l}\text { Chl } \alpha_{1} \\
\left(\operatorname{ng} 1^{-1}\right)\end{array}$ \\
\hline \multirow[t]{5}{*}{5} & 5 & 120770 & 2513 & 908 & $n d^{a}$ & - & $\mathrm{nd}^{\mathrm{d}}$ \\
\hline & 80 & 170345 & 2189 & 799 & 26.3 & 0.15 & 38.2 \\
\hline & 90 & 100453 & 770 & 1177 & 42.7 & 0.43 & 62.3 \\
\hline & 100 & 59818 & 243 & 805 & 41.8 & 0.70 & 56.1 \\
\hline & 110 & 22130 & 124 & 462 & 13.6 & 0.61 & 25.7 \\
\hline \multirow[t]{4}{*}{6} & 57 & 186568 & 4884 & 1225 & 16.0 & 0.09 & 37.9 \\
\hline & 70 & 76948 & 5117 & 3310 & 42.8 & 0.56 & 155.2 \\
\hline & 80 & 69584 & 1256 & 1026 & 64.2 & 0.92 & 80.8 \\
\hline & 100 & 55576 & 588 & 1035 & 49.4 & 0.89 & 58.3 \\
\hline \multirow[t]{5}{*}{7} & 110 & 37512 & 87 & 192 & 19.2 & 0.51 & 23.9 \\
\hline & 120 & 58825 & 51 & 895 & 35.3 & 0.60 & 37.6 \\
\hline & 130 & 34377 & 35 & 529 & 36.1 & 1.05 & 35.7 \\
\hline & 165 & 4478 & 0 & 154 & 6.5 & 1.45 & 14.3 \\
\hline & 250 & 183 & 18 & 0 & nd & - & nd \\
\hline
\end{tabular}

Discussion. The DCM was a constant feature of our study, with a sharp peak in fluorescence found at all stations during both years. It appeared to be associated with the pycnocline and with the steepest gradient in dissolved inorganic nitrogen (DIN), as observed in many other studies (cf. Riley 1938, Veldhuis \& Kraay 1990, Varela et al. 1992, Campbell \& Vaulot 1993, Estrada et al. 1993). Cullen (1982) referred to this pattern as the 'typical tropical structure' type of DCM. Subsurface maxima in both productivity and chlorophyll in such systems presumably result from enhanced nutrient flux due to higher DIN concentrations at the base of the pycnocline.

The most striking feature of the DCM in our study was the high and constant proportion of chl $a_{2}$, indicating very high concentrations of prochlorophytes. In all of our samples these were clearly the most abundant phytoplankters by number, as confirmed by the flow cytometry (Table 3), ranging 1 to 2 orders of magnitude higher in abundance than the coccoid cyanobacteria and the eukaryotic phytoplankton. The constancy in the proportion of chl $a_{2}$ to total chl a suggests either that processes regulating prochlorophyte biomass are the same as those for chl $a_{1}$-containing phytoplankton or that processes regulating pigment/ biomass ratios are the same, or both. It is not possible to distinguish between these possibilities without more data on grazing mortalities and growth rates. Our data indicate a very wide range in prochlorophyte pigment concentrations per cell, however, from 0.09 (Stn 6, $57 \mathrm{~m}$; Table 3) to $1.45 \mathrm{fg}$ cell ${ }^{-1}$ (Stn 7, $165 \mathrm{~m}$ ) for chl $a_{2}$. At Stn 6 , cell pigment content increased nearly an order of magnitude over only a $43 \mathrm{~m}$ depth range
(Table 3). Although the magnitude is somewhat less, the range we observed is greater than that seen by Veldhuis \& Kraay (1990) in the subtropical Atlantic ( 0.91 to $5.4 \mathrm{fg} \mathrm{cell}^{-1}$ ). Thus, chl $a_{2}$ is not very accurate as a biomass indicator for prochlorophytes when sampling over several optical depths, and this supports the idea that a large part of the DCM is due to increases in pigment per cell, rather than real biomass increases (Steele 1964, Cullen 1982, Campbell \& Vaulot 1993).

$\mathrm{Chl} b / \mathrm{chl} a_{2}$ also increased markedly with depth through the DCM (Fig. 4). If all of the $\operatorname{chl} b$ were attributed to the prochlorophytes, then $b / a$ ratios exceeding 3 were maintained by these picoplankters in the deeper parts of the DCM. Even if a correction is made for the prasinophytes (using a chl $b$ /prasinoxanthin ratio of 2.08 from Everitt et al. 1990, they accounted for $13.7 \%$ of the chl $b$ on average), the ratio in prochlorophytes often exceeded 2.5. This is much higher than that reported for eukaryotic phytoplankton (reviewed by Wood 1979, average b/a of 0.46 for 25 species), and higher than the value of 0.8 observed in the tropical Atlantic by Gieskes \& Kraay (1986; ratio of chl $b$

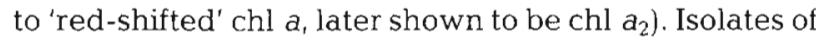
Prochlorococcus marinus increase their $b / a$ ratio in response to decreased light, though the cultures examined to date do not exceed a ratio of 1.6 (Partensky et al. 1993). Other microalgae that contain chl $b$ maintain a relatively constant $b / a$ ratio, increasing both pigments equally in low light conditions (e.g. Jeffrey 1984). Thus, this dramatic shift in the b/a ratio in prochlorophytes may be a chromatic adaptation to increasing proportion with depth of blue light, which is harvested more efficiently by chl $b$ than by chl $a$. This would be analagous 


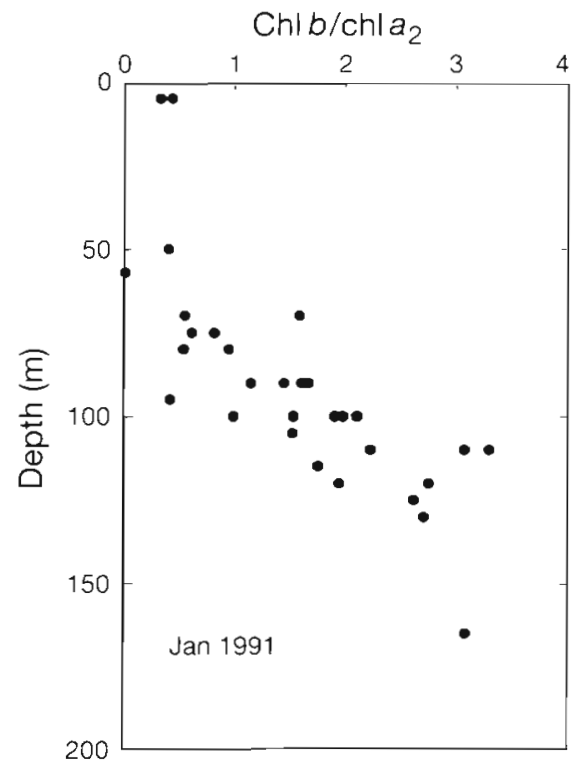

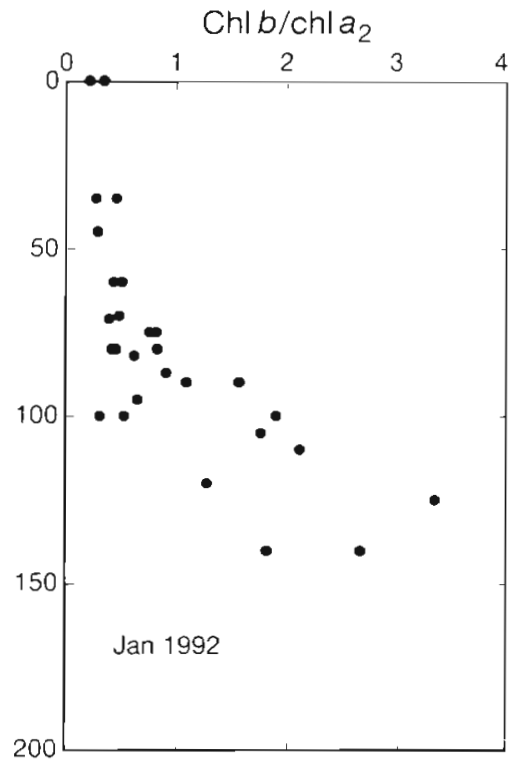

Fig. 4. Summary data, all stations, all depths, for chl $b / c h l a_{2}$ to the increased phycobiliprotein/ chlorophyll a ratios in coccoid cyanobacteria under biue-green light (Jeffrey 1984). However, some of our flow cytometry samples showed a bimodal distribution of fluorescence intensities for prochlorophytes in the DCM, suggesting the possibility of 2 distinct populations, as observed in the tropical Pacific (Campbell \& Vaulot 1993). We thus cannot rule out the possibility that the increased $b / a$ ratios reflect changing proportions of 2 prochlorophyte types with depth in the DCM, rather than chromatic adaptation within a single population.

Carotenoid concentrations varied with depth in the DCM in a way that generally supports the idea of increased relative biomass of eukaryotes at the bottom of the DCM (Furuya \& Marumo 1983, Murphy \& Haugen 1985, Glover et al. 1986a, b, 1987). Relative to chl $a_{1}$, both 19'-butanoyl-oxy-fucoxanthin and 19'-hexanoyloxy-fucoxanthin increased with depth through the DCM $\left(\mathrm{R}^{2}=0.52\right.$ and 0.33 ; respectively; $\mathrm{p}<0.01$ for both), while fucoxanthin did not change significantly and prasinoxanthin increased only slightly $\left(R^{2}=0.20\right.$; $\mathrm{p}<0.05$; Fig. 5). The same trends are apparent in the carotenoid to total chl a ( $\left.\mathrm{chl} a_{1}+\mathrm{chl} \mathrm{a}_{2}\right)$ ratios. It is not certain to what extent these changes reflect biomass changes or photoadaptive adjustments of pigment concentrations per cell. Most studies have shown that eukaryotic micro-algae respond to both decreases in light and spectral shifts toward blue-green light by increasing total pigment without changing the relative proportions of chlorophyll and accessory pigments, except for small changes in the ratio of chl $c$ to $\operatorname{chl} a$ (Vesk \& Jeffrey 1977, Kamiya \& Miyachi 1980, Jeffrey

\section{Carotenoid/chl $a_{1}$}

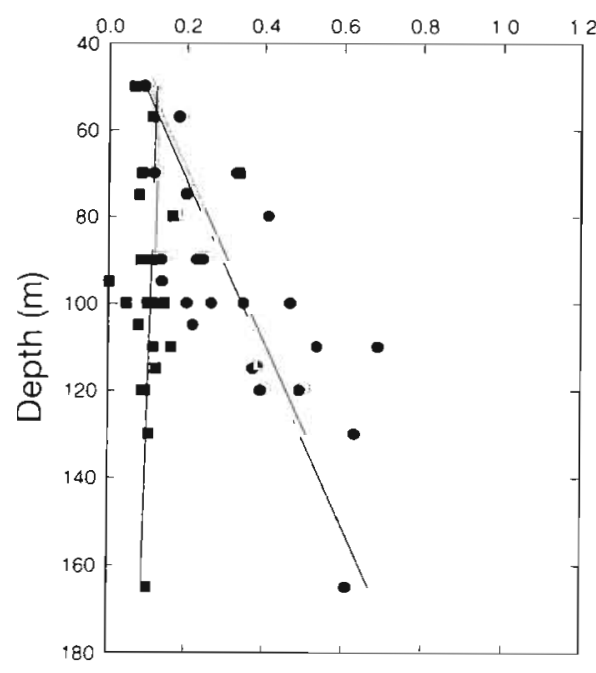

Carotenoid/chla

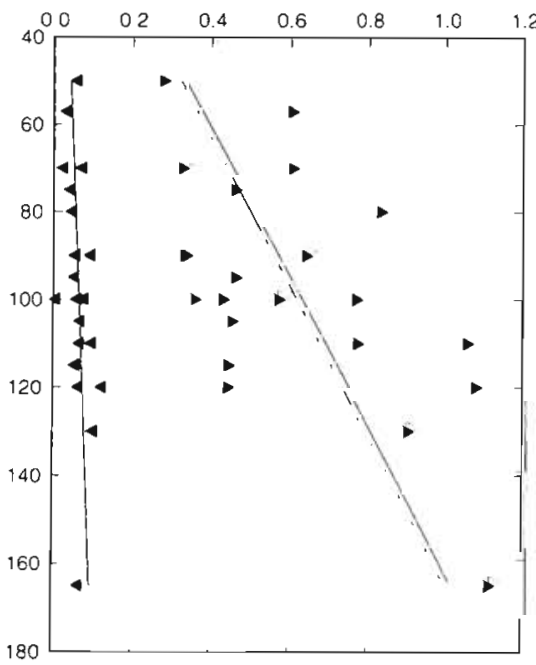

Fig. 5. Carotenoid/chla, ratios versus depth in the DCM. (-) Fucoxanthin; (•) 19'-butanoyl-oxy-fucoxanthin; ( 19'-hexanoyl-oxy-fucoxanthin; (4) prasinoxanthin. Lines are least-squares regressions 
1984). This suggests that the carotenoid increases we observed represent real increases in the relative proportion of some eukaryotes (e.g. some chrysophytes and prymnesiophytes, characterized by $19^{\prime}$-butanoyloxy-fucoxanthin and 19'-hexanoyl-oxy-fucoxanthin, respectively) in the deepest parts of the DCM. Flow cytometry showed that eukaryotic phytoplankters had their highest percentage of the total cell numbers at the deepest depths at 2 of the 3 flow cytometry stations, and their lowest relative abundance at the shallowest DCM depths at all 3 stations (Table 3 ), further supporting the idea that they are more characteristic of the bottom of the DCM.

Zeaxanthin/chl $a_{1}$ did not change systematically in the DCM, though it was higher in the 2 surface samples $(5 \mathrm{~m})$. Both coccoid cyanobacteria and prochlorophytes contain this photoprotective carotenoid, so its vertical distribution should reflect both the relative abundances of these picoplankters and their respective concentrations per cell. In cultures of Synechococcus sp., zeaxanthin per cell does not change with irradiance (Kana et al. 1988), whereas a recent study by Partensky et al. (1993) showed it to increase with light in 2 strains of Prochlorococcus and decline in another. In the Caribbean, there might also be contributions to zeaxanthin concentrations in the DCM from sinking larger phytoplankton, especially the filamentous cyanobacterium Trichodesmium, which was abundant near the surface at all of our stations.

Our results extend to the Caribbean and western tropical Atlantic Ocean the observations of other investigators working on picoplankton distributions in the DCM of tropical waters. In common with Campbell \& Vaulot (1993) and Shimada et al. (1993), we found prochlorophytes to dominate cell abundance, with coccoid cyanobacteria being of minor importance. The relative constancy of prochlorophytes in relation to other phytoplankton, as reflected in both the cell counts and the chl $a_{2} / \mathrm{chl} a_{1}$ ratio suggests that growth and mortality are closely coupled within the DCM. More studies of these processes are needed to shed further light on the persistence of deep chlorophyll maxima and the dominance of prochlorophytes in tropical oceans.

Acknowledgements. We thank D. Capone and E. Carpenter for space on their cruises, N. Welschmeyer, J. Waterbury and R. Goericke for helpful discussion, and C. Keefe for nutrient analyses. Fig. 1 was drawn using the computer program OPCPLOT, kindly supplied by $M$. Brown. We also thank A. Subramaniam for light data and R. Olson, who performed the flow cytometry while supported by OCE 90-12147 and ONR grant N00014-87-K-0007, and commented on an earlier version of the manuscript. This research was supported by NSF grants OCE 90-12553, OCE 92-03478 (G.B.M.) and OCE 89-023063 (R.D.)

\section{LITERATURE CITED}

Bianchi, T S., Findlay, S., Daw'son, R. (1993). Organic matter sources in the water column and sediments of the Hudson River Estuary: the use of plant pigments as tracers. Estuar. coast. Shelf Sci. 36: 1-6

Campbell, L., Vaulot, D. (1993). Photosynthetic picoplankton community structure in the subtropical North Pacific Ocean near Hawaii (station ALOHA). Deep Sea Res. 40: 2043-2060

Chisholm, S. W., Frankel, S. L., Goericke, R., Olson, R. J., Palenik, B., Waterbury, J. B., West-Johnsrud, L., Zettler, E. R. (1992). Prochlorococcus marinus nov. gen. nov. sp. an oxyphototrophic marine prokaryote containing divinyl chlorophyll $a$ and $b$. Arch. microbiol. 157: 297-300

Chisholm, S. W., Olson, R. J., Zettler, E. R., Goericke, R., Waterbury, J. B., Welschmeyer, N. A. (1988). A novel freeliving prochlorophyte abundant in the oceanic euphotic zone. Nature 334: 340-343

Cullen, J. J. (1982). The deep chlorophyll maximum: comparing vertical profiles of chlorophyll a. Can. J. Fish. Aquat. Sci. 39: 791-803

Estrada, M., Marrase, C., Latasa, M., Berdalet, E., Delgado, M., Riera, T. (1993). Variability of deep chlorophyll maximum characteristics in the northwest Mediterranean. Mar. Ecol. Prog. Ser. 92: 289-300

Everitt, D. A., Wright, S. W., Volkman, J. K., Thomas, D. P. Lindstrom, D. P. (1990). Phytoplankton community compositions in the western equatorial Pacific determined from chlorophyll and carotenoid pigment distributions. Deep Sea Res. 37: 975-997

Furuya, K., Marumo, R. (1983). The structure of the phytoplankton community in the subsurface chlorophyll maxima in the western North Pacific Ocean. J. Plankton Res. 5: $393-406$

Gieskes, W. W., Kraay, G. W. (1983). Unknown chlorophyll a derivatives in the North Sea and the tropical Atlantic Ocean revealed by HPLC analysis. Limnol. Oceanogr. 28: $757-766$

Gieskes, W. W. C., Kraay, G. W. (1986). Floristic and physiological differences between the shallow and deep nanoplankton community in the euphotic zone of the open tropical Atlantic revealed by HPLC analysis of pigments. Mar. Biol. 91: 567-576

Glover, H. E., Campbell, L., Prezelin, B. B. (1986a). Contribution of Synechococcus spp. to size-fractionated primary productivity in three water masses in the Northwest Atlantic Ocean. Mar. Biol. 91: 193-203

Glover, H. E., Keller, M. D., Guillard, R. R. L. (1986b). Light quality and oceanic ultraphytoplankters. Nature 319 : $142-143$

Glover, H. E., Keller, M. D., Spinrad, R. W. (1987). The effects of light quality and intensity on photosynthesis and growth of marine eukaryotic and prokaryotic phytoplankton clones. J. exp. mar. Biol. Ecol. 105; 137-159

Goericke, R., Repeta, D. (1992). The pigments of Prochlorococcus marinus: the presence of divinyl chlorophylis a and $b$ in a marine prokaryote. Limnol. Oceanogr. 37: 425-433

Goericke, R., Repeta, D. (1993). Chlorophylls $a$ and $b$ and divinyl chlorophylls $a$ and $b$ in the open subtropical North Atlantic Ocean. Mar. Ecol. Prog. Ser. 101: 307-313

Goericke, R., Welschmeyer, N. A. (1993). The marine prochlorophyte Prochlorococcus contributes significantly to phytoplankton biomass and primary production in the Sargasso Sea. Deep Sea Res. 40: 2283-2294

Hooks, C. E., Bidigare, R. R., Keller, M. D., Guillard, R. R. L. (1988). Coccoid eukaryotic marine ultraplankters with 
four different HPLC pigment signatures. J. Phycol. 24 $571-580$

Iturriaga, R., Mitchell, B. G. (1986). Chroococcoid cyanobacteria: significant component in the food web dynamics of the open ocean. Mar. Ecol. Prog. Ser. 28: 281-297

Jeffrey, S. W. (1984). Responses of unicellular marine plants to natural blue-green light environments. In: Senger, $H$. (ed.) Blue light effects in biological systems. Springer, Berlin, p. $497-508$

Jochem, F. J., Zeitzschel, B. (1993). Productivity regime and phytoplankton size structure in the tropical and subtropical North Atlantic in spring 1989. Deep Sea Res. 240: 495-519

Johnson, P. W., Sieburth, J. M. (1982). In situ morphology and occurrence of eucaryotic phototrophs of bacterial size in the picoplankton of estuarine and oceanic waters. $\mathrm{J}$. Phycol. 18: 318-327

Kana, T M., Glibert, P. M., Goericke, R., Welschmeyer, N. A. (1988). Zeaxanthin and $\beta$-carotene in Synechococcus WH7803 respond differently to irradiance. Limnol. Oceanogr. 33: 1623-1627

Kamiya, A., Miyachi, S. (1980). Blue light effects on some algae collected from subsurface chlorophyll layer in the western Pacific Ocean. In: Senger, H. (ed.) The blue light syndrome. Springer, Berlin, p. 605-615

Li, W. K. W., SubbaRao, D. V., Harrison, W. F., Smith, J. C., Cullen, J. J., Irwin, B., Platt, T. (1983). Autotrophic picoplankton in the tropical ocean. Science 219: 292-295

Li, W. K. W., Wood, A. M. (1988). Vertical distribution of North Atlantic ultraphytoplankton: analysis by flow cytometry and epifluorescence microscopy. Deep Sea Res. 35 $1615-1638$

Mantoura, R. F. C., LLewellyn, C. A. (1983). The rapid determination of algal chlorophyll and carotenoid pigments and their breakdown products in natural waters by reversephase high-performance liquid chromatography. Analytica chim. Acta 151: 297-314

Murphy, L. S., Haugen, E. M. (1985). The distribution and abundance of phototrophic ultraplankton in the North Atlantic. Limnol, Oceanogr. 30: 47-58

Olson, R. J., Chisholm, S. W., Zettler, E. R., Altabet, M. A., Dusenberry, J. A. (1990). Spatial and temporal distributions of prochlorophyte picoplantkon in the North Atlantic Ocean. Deep Sea Res. 37: 1033-1051

Olson, R. J., Zettler, E. R., DuRand, M. D. (1993). Phytoplankton analysis using flow cytometry. In: Kemp, P. F., Sherr, B. F., Sherr, E. B., Cole, J. J. (eds.) Handbook of methods in aquatic microbial ecology. Lewis Publishers, Ann Arbor, p. 175-186

Palenik, B. P., Haselkorn, R. (1992). Multiple evolutionary origins of prochlorophytes, the chlorophyll $b$-containing prokaryotes. Nature 355: 265-267

Parsons, T R., Maita, Y., Lalli, C. M. (1984). A manual of chemical and biological methods for seawater analysis. Pergamon, New York

This note was presented by B. \& E. Sherr (Senior Editorial Advisors), Corvallis, Oregon, USA.
Partensky, F., Hoepffner, N., Li, W. K. W., Ulloa, O., Vaulot, D. (1993). Photoacclimation of Prochlorococcus sp. (Prochlorophyta) strains isolated from the North Atlantic and the Mediterranean Sea. Plant Physiol. 101. 285-296

Riley, G. A. (1938). Plankton studies I. A preliminary investigation of the plankton of the Tortugas region. J. mar. Res. 1: $335-352$

Rowan, K. S. (1989). Photosynthetic pigments of algae. Cambridge University Press, Cambridge

Shimada, A., Hagesawa, T., Umeda, I., Kadoya, N., Maruyama, T. (1993). Spatial mesoscale patterns of West Pacific picophytoplankton as analyzed by flow cytometry: their contribution to subsurface chlorophyll maxima. Mar. Biol. 115: $209-215$

Steele, J. H. (1964). A study of production in the Gulf of Mexico. J. mar. Res. 22: 211-222

Stockner, J. G., Antia, N. J. (1986). Algal picoplankton from marine and freshwater ecosystems: a multidisciplinary perspective. Can. J. Fish. Aquat. Sci. 43: 2472-2503

Takahashi, M., Hori, T. (1984). Abundance of picophytoplankton in the subsurface chlorophyll maximum layer in subtropical and tropical waters. Mar. Biol. 79: 177-186

Urbach, E, Robertson, D., Chisholm, S. W. (1992). Multiple evolutionary origins of prochlorophytes within the cyanobacterial radiation. Nature 355: 267-269

Varela, R. A., Cruzado, A., Tintore, J., Ladona, E. G. (1992). Modelling the deep-chlorophyll maximum: a coupled physical-biological approach. J. mar. Res. 50: 441-463

Vaulot, D., Partensky, F., Neveux, J., Mantoura, R. F. C., Llewellyn, C. A. (1990). Winter presence of prochlorophytes in surface waters of the northwestern Mediterranean Sea. Limnol. Oceanogr. 35: 1156-1164

Veldhuis, M. J. W., Kraay, G. W. (1990). Vertical distribution and pigment composition of a picoplanktonic prochlorophyte in the subtropical North Atlantic: a combined study of HPLC-analysis of pigments and flow cytometry. Mar. Ecol. Prog. Ser. 68: 121-127

Venrick, E. L. (1993). Phytoplankton seasonality in the central North Pacific: the endless summer reconsidered. Limnol. Oceanogr. 38: 1135-1149

Vesk, M., Jeffrey, S. W. (1977). Effect of blue-green light on photosynthetic pigments and chloroplast structure in unicellular marine algae from six classes. J. Phycol. 13: 280-288

Wood, A. M. (1979). Chlorophyll a:b ratios in marine planktonic algae. J. Phycol. 15: 330-332

Wright, S. W., Shearer, J. D. (1984). Rapid extraction and high performance liquid chromatography of chlorophylls and carotenoids from marine phytoplankton. J. Chromatography 294: 281-295

Wright, S. W., Jeffrey, S. W., Mantoura, R. F. C., Llewellyn, C. A., Bjørnland, T., Repeta, D. Welschmeyer, N. (1991). Improved HPLC method for the analysis of chlorophylls and carotenoids from marine phytoplankton. Mar. Ecol. Prog. Ser. 77 : 183-196

Manuscript first received: December 7, 1993

Revised version accepted: May 31, 1994 